\title{
Pengaruh Integritas dan Moralitas Individu pada Kecurangan Akuntansi dengan Sistem Pengendalian Internal sebagai Variabel Mediasi
}

\author{
I Kadek Yogi Anggara ${ }^{1}$ \\ Fakultas Ekonomi danBisnis \\ UniversitasiUdayana, Indonesia
}

\author{
Herkulanus Bambang Suprasto ${ }^{2}$ \\ Fakultas Ekonomi dan Bisnis \\ Universitas Udayana, Indonesia
}

Surel : ikadekyogianggara@gmail.com

\section{ABSTRAK}

Penelitian ini bertujuan untuk mengetahui pengaruh integritas dan moralitas individu pada kecurangan akuntansi dengan sistem pengendalian internal sebagai variabel mediasi. Populasi adalah 37 OPD Kabupaten Badung. Penentuan sampel menggunakan purposive sampling dengan 74 responden. Hasil penelitian menunjukkan integeritas dan moralitas individu berpengaruh negatif terhadap kecurangan akuntansi, integritas dan moralitas Individu berpengaruh positif terhadap sistem pengendalian internal dan sistem pengendalian internal berpengaruh negatif terhadap kecurangan akuntansi. Sistem pengendalian internal memediasi secara parsial pengaruh negatif Integritas terhadap Kecurangan akuntansi. Sistem pengendalian internal tidak memediasi pengaruh negatif Moralitas Individu terhadap Kecurangan akuntansi. Hasil penelitian diharapkan mampu memberikan pandangan untuk lebih memperhatikan sistem pengendalian internal karena dapat mempengaruhi memediasi integritas terhadap kecurangan akuntansi.

Kata Kunci: Kecurangan; Kecurangan Akuntansi; Organisasi Perangkat Daerah.

\section{The Influence of Time Budget Pressure, Audit Complexity and Audit Fee on Audit Quality}

\section{ABSTRACT}

This study aims to determine the effect of integrity and morality of individuals on accounting fraud with internal control systems as a mediating variable. The population in this study are 37 Regional Organizations in Badung. Determination of the sample using purposive sampling with 74 respondents. The results showed that individual integrity and morality had a negative effect on accounting fraud, integrity and morality of individuals had a positive effect on the internal control system and the internal control system had a negative effect on accounting fraud. Internal control system partially mediates the negative effect of Integrity on accounting fraud. Internal control system does not mediate the negative effect of Individual Morality on Accounting Fraud. The results are expected to be able to provide insight for relevant parties to pay more attention to internal control systems because they can influence mediating integrity against accounting fraud.

Keywords: Cheating; Aaccounting Fraud; Regional Organizations.

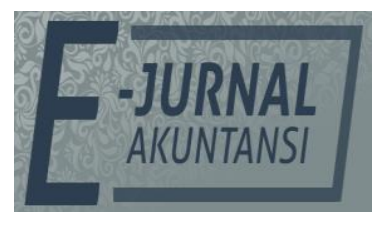

e-ISSN 2302-8556

Vol. 30 No. 9

Denpasar, September 2020

Hal. 2296-2310

DOI:

10.24843/EJA.2020.v30.i09.p10

PENGUTIPAN:

Anggara, I K. Y. \& Suprasto,

H. B. (2020). Pengaruh

Integritas dan Moralitas

Individu pada Kecurangan

Akuntansi dengan Sistem

Pengendalian Internal sebagai Variabel Mediasi. EJurnal Akuntansi, 30(9), 2296-

2310

RIWAYAT ARTIKEL: Artikel Masuk: 15 Juni 2020 Artikel Diterima: 25 Agustus 2020

Artikel dapat diakses : https://ojs.unud.ac.id/index.php/Akuntansi/index 


\section{PENDAHULUAN}

Banyaknya tuntutan untuk menghasilkan laporan keuangan yang berkualitas tidak menutup kemungkinan akan adanya perilaku disfungsional dari para penyusun laporan keuangan, sehingga pelaporan menguntungkan pihak tertentu. Perilaku yang tidak semestinya dari para penyusun laporan keuangan diakibatkan kurangannya kejujuran dan adanya kesempatan untuk melakukan kecurangan. Kecurangan yang dilakukan dapat berupa penghilangan jumlah atau pengungkapan dalam laporan keuangan untuk mengelabui pemakai laporan keuangan.

Kecurangan (fraud) adalah bentuk kecurangan yang sengaja dilakukan oleh seseorang atau kelompok orang sehingga dapat menimbulkan kerugian terhadap pihak tertentu. Menurut Suci \& Lisda (2016), pada umumnya kecurangan akuntansi berkaitan dengan korupsi. Dalam korupsi, tindakan yang lazim dilakukan adalah memanipulasi, pencatatan, penghilangan dokumen, dan markup yang merugikan keuangan atau perekonomian negara. Kecenderungan menunjukan adanya indikasi untuk melakukan tindakan yang mengarah adanya kecurangan. Kecurangan akuntansi dapat dikatakan sebagai tendensi korupsi dalam definisi dan terminologi karena keterlibatan beberapa unsur yang terdiri dari fakta-fakta menyesatkan, pelanggaran aturan atau penyalahgunaan kepercayaan, dan omisi fakta kritis (Locatelli, 2017).

Ilter (2017), Kecurangan akuntansi (fraud) mengacu kepada kesalahan akuntansi yang dilakukan secara sengaja dengan tujuan menyesatkan pembaca/pengguna laporan keuangan. Tujuan ini dilakukan dengan motivasi negatif guna mengambil keuntungan individu atau pihak-pihak tertentu. Menurut Sari Dewi (2016) kecurangan merupakan segala sesuatu yang secara lihai dapat digunakan untuk mendapatkan keuntungan dengan cara menutupi kebenaran, tipu daya, kelicikan atau mengelabui dan cara tidak jujur yang lain. Dari perspektif kriminal, kecurangan akuntansi dikategorikan sebagai kejahatan kerah putih (white-collar crime). Perilaku kecurangan dijelaskan oleh Fraud Triangle Teory. Seseorang melakukan kecurangan karena adanya tekanan, kesempatan dan rasionalisasi. Menurut Junaidi \& Siti (2017), faktor rasionalisasi dan tekanan merupakan karakteristik pelaku kecurangan akuntansi yang tidak dapat diobservasi karena mustahil untuk mengetahui apa yang dipikirkan oleh pelaku ketika akan melakukan kecurangan akuntansi.

Kecurangan akuntansi ini dapat disebabkan oleh faktor linkungan tempat bekerja dan individu itu sendiri. Faktor kecurangan akuntansi yang berasal dari dalam diri sendiri dapat tejadi karena lemahnya komitmen pribadi yang memnyebabkan seseorang melakukan kecurangan. Salah satu idikasi yang menjadi tolak ukur lemahnya komitmen pribadi adalah integritas individu. Integritas adalah suatu komitmen pribadi yang teguh terhadap prinsip ideologi yang etis dan menjadi bagian dari konsep diri yang ditampilkan melalui perilakunya. Integritas mengharuskan seseorang untuk bersikap jujur dan transparan, berani, bijaksana dan bertanggung jawab. Banyak masalah keuangan atau kecurangan akuntansi yang terjadi dapat menunjukkan suatu bentuk kegagalan integritas laporan keuangan untuk memenuhi kebutuhan informasi pengguna laporan keuangan. 
Kecurangan akuntansi sangat erat hubungannya dengan etika. Etika menggunakan teori perkembangan moral untuk mengobservasi dasar individu melakukan suatu tindakan. Mengetahui level penalaran moral seseorang akan menjadi dasar untuk mengetahui kecenderungan individu melakukan suatu tindakan tertentu, terutama yang berkaitan dengan dilema etika, berdasarkan level penalaran moralnya. Moralitas individu merupakan salah satu faktor dari dalam diri individu yang memengaruhi terjadinya kecurangan akuntansi dan perilaku tidak etis. Organisasi atau instansi juga memiliki tanggung jawab moral. Tanggung jawab moral dari manajemen organisasi mempengaruhi terjadinya perilaku tidak etis dan kecurangan akuntansi.

Berdasarkan Indeks Persepsi Korupsi (IPK) dari penyataan Indonesia Corruption Watch (ICW) tahun 2018 Indonesia menempati posisike-89 dari 180 negara. Pada tahun 2018 ICW menemukan ada sebanyak 454 kasus korupsi yang ditangani oleh penegak hukum. Total tersangka yang ditetapkan yakni sebanyak 1.087 orang dengan berbagai latar belakang profesi. Indonesia Corruption Watch (ICW) menyatakan bahwa tata-rata kasus dugaan korupsi yang ditangani oleh penegak hukum selama empat tahun yaitu tahun 2015 s.d. 2018 sebanyak 392 kasus pertahun. Rata-rata aktor yang ditetapkan sebagai tersangka korupsi sebanyak 1.153 orang. Rata-rata kerugian negara yang ditimbulkan akibat korupsi sebesar Rp 4,17 triliun.

Banyak kasus kecurangan lain dalam akuntansi yang akhirnya terungkap di Indonesia seperti kasus kejahatan perbankan, manipulasi pajak, keterlibatan 10 Kantor Akuntan Publik (KAP) dalam pelaksanakan audit 37 bank sebelum terjadinya krisis keuangan pada tahun 1997, diajukan manajemen Badan Usaha Milik Negara (BUMN) dan swasta ke pengadilan, serta korupsi di komisi penyelenggara pemilu (Putra, 2012). Berita kecurangan akuntansi bukan menjadi rahasia lagi karena di era ini berita dapat tersebar dengan cepat, baik itu media cetak (koran dan majalah), media elektronik (televisi dan radio) dan media massa internet.

Organisasi sektor publik yang sering dihubungkan dengan pemerintah yang bertanggungjawab untuk melakukan pelayanan publik untuk memenuhi kesejahteraan di berbagai bidang kehidupan. Pemerintah merupakan entitas publik yang harus mempertanggungjawabkan kinerjanya dalam bentuk laporan keuangan. Laporan keuangan pemerintah yang dihasilkan harus memenuhi prinsip-prinsip tepat waktu dan disusun dengan mengikuti Standar Akuntansi Pemerintahan sesuai dengan Peraturan Pemerintah Nomor 71 Tahun 2010. Fenomena kualitas laporan keuangan pemerintah di Indonesia merupakan sesuatu hal yang menarik untuk dikaji lebih lanjut. Dasar pemikiran ini berasal dari fakta bahwa terdapat penyimpangan-penyimpangan yang berhasil ditemukan oleh Badan Pemeriksa Keuangan dalam pelaksanaan audit laporan keuangan pemerintah.

Badan Pemeriksaan Keuangan (BPK) mengungkapkan pengawasan internal di pemerintahan provinsi maupun kabupaten/kota di Bali oleh inspektorat masing-masing, dirasakan masih sangat lemah. Akibatnya, banyak penyimpangan dalam pengelolaan anggaran yang lolos begitu saja. Contohnya dalam kasus pengadaan barang dan jasa di Porprov Bali. Banyak yang menjadi temuan kemahalan oleh Badan Pemeriksaan Keuangan (BPK), tetapi malah hal 
itu tidak menjadi temuan dan atensi pencegahan inspektorat. BPK juga mengkritisi lemahnya pengawasan internal oleh jajaran inspektorat di Bali. Padahal, inspektorat berperan penting dalam mengawasi dan mencegah penyimpangan dalam penyelenggaraan pemerintahan maupun pelaksanaan APBD.

Hasil pemeriksaan BPK tahun 2018, Pemerintahan Daerah Kabupaten Badung pada tahun 2008, BPK RI memberikan opini "Tidak memberikan pendapat", pada tahun 2013 BPK RI memberikan opini "Tidak Wajar". Selanjutnya pada Tahun 2014 hingga tahun 2017 berturut - turut BPK RI memberikan opini "Wajar Tanpa Pengecualian" dalam menyajikan laporan keuangan Pemerintah Daerah. Meskipun opini yang dierikan BPK tersebut baik pada Pemerintah Kabupaten Badung, namun dari pelaksanaan pemeriksaan di lapangan, BPK masih menemukan beberapa kelemahan dalam sistem pengendalian intern dan temuan yang terkait dengan kepatuhan terhadap peraturan perundang-undangan. BPK perwakilan Bali menemukan beberapa permasalahan yakni dalam pencatatan dan pelaporan asset yang belum jelas, pendapatan restribusi daerah, pendapatan atas sewa belum diatur, penerimaan daerah, penatausahaan aset tetap, realisasi belanja dan BPK juga menekankan agar perangkat daerah melaksanakan kepatuhan terhadap aturan yang berlaku serta melaksanakan sistem pengendalian internal. Berdasarkan fenomena tersebut dapat dinyatakan bahwa laporan keuangan pemerintah daerah masih belum seluruhnya memenuhi karakteristik kualitatif yang disyaratkan, sehingga diperlukan pembenahan terhadap sistem kerja pada pegawai pemerintah daerah terutama pada bagian penatausahaan keuangan dan sistem pengendalian internal (Prihartono \& Mayangsari, 2018).

Opini BPK merupakan salah satu indikator yang digunakan oleh para pemangku kepentingan (stakeholders) untuk mendapatkan tingkat kepercayaan atas sebuah laporan keuangan yang disajikan. Pemilihan Kabupaten Badung ini karena Kabupaten Badung sumbang pertumbuhan ekonomi Bali terbesar dimana pertumbuhan ekonomi Kabupaten Badung yang mencapai 7,3 $\mathrm{T}$ dalam tahun 2012 disertai dengan distribusi pendapatan dengan pemerataan yang tinggi, terjadinya penurunan tingkat kemiskinan yang cukup signifikan dalam tahun 2013 serta terjadinya peningkatan belanja APBD dalam tahun 2014 ini tembus 3,2 T sebagai akibat meningkatnya pendapatan asli daerah yang bersumber dari pendapatan atas Pajak dan restoran sehingga hal ini juga berimplikasi terhadap peningkatan besarnya bantuan keuangan kepada provinsi dan enam kabupaten se-Bali yang dalam tahun 2013 mencapai 195 Milyar lebih semntara dalam tahun 2014 di anggaran induk ini mencapai 187 M lebih. melalui peningkatan belanja ini maka pemerintah Kabupaten Badung juga dapat meningkatkan besarnya anggaran pada berbagai bidang dan sektor termasuk pada pembangunan di sektor pertanian terutama melalui pembangunan petani mandiri dan sejahtera (TANIMAS) dengan anggaran dalam tahun 2014 ini sebesar 4,3 Milyar lebih.

Berdasarkan penelitian terdahulu yang dilakukan oleh Lestari \& Dewi (2020) menunjukkan hasil bahwa integritas berpengaruh negatif terhadap kecurangan akuntansi. Integritas dapat mengurangi tindakan kecurangan. Penelitian Lestari \& Supadmi (2017) mengenai kucurangan akuntansi menunjukkan bahwa integritas berpengaruh negatif terhadap kecurangan 
akuntansi. Chandrayatna (2019) dan Udayani \& Sari (2017) menyimpulkan bahwa moralitas individu berpengaruh negatif terhadap kecurangan akuntansi. Hasil tersebut juga sejalan dengan penelitian yang dilakukan oleh Eliza (2015) berpendapat bahwa moralitas individu berpengaruh negatif dan signifikan terhadap tingkat kecenderungan kecurangan akuntansi.

Sudarman \& Kusuma (2019) menyatakan bahwa moralitas berinteraksi positif dengan pengendalian internal. Hal tersebut memiliki makna jika seseorng karyawan memiliki moralitas individu yang baik maka hal tersebut akan membuat karyawan memiliki pengendalian diri yang baik. Penelitian Yadnya (2017) menyatakan "secara parsial Moralitas individu dan efektivitas system pengendalian internal berpengaruh negatif terhadap kecenderungan kecurangan akuntansi, artinya semakin efektif pengendalian internal perusahaan, semakin rendahnya kecurangan akuntansi di organisai." Menurut Donelson \& Ege (2019) kesempatan yaitu peluang yang menyebabkan pelaku secara leluasa menjalankan aksinya yang disebabkan oleh pengendalian internal yang lemah, ketidakdisiplinan, kelemahan dalam mengakses informasi, tidak ada mekanisme audit, dan sikap apatis. Coram (2018) menjelaskan bahwa organisasi yang memiliki fungsi internal audit akan lebih dapat mendeteksi kecurangan akuntansi. Penelitian Zager et al. (2016) menemukan bahwa auditor berperan dalam mengurangi faktor kesempatan (opportunity) dalam kecurangan akuntansi.

Penelitian ini bertujuan untuk menguji pengaruh integritas dan moralitas individu pada kecurangan akuntansi dengan sistem pengendalian internal sebagai variabel mediasi. Dimana sistem integritas $\left(X_{1}\right)$ dan moralitas individu $\left(\mathrm{X}_{2}\right)$, dan merupakan variabel independent, kecurangan akuntansi (Y) merupakan variabel dependen dan sistem pengendalian internal $(Z)$ sebagai variable mediasi. Hubungan variabel-variabel tersebut jika digambarkan melalui kerangka konseptual pada gambar 1.

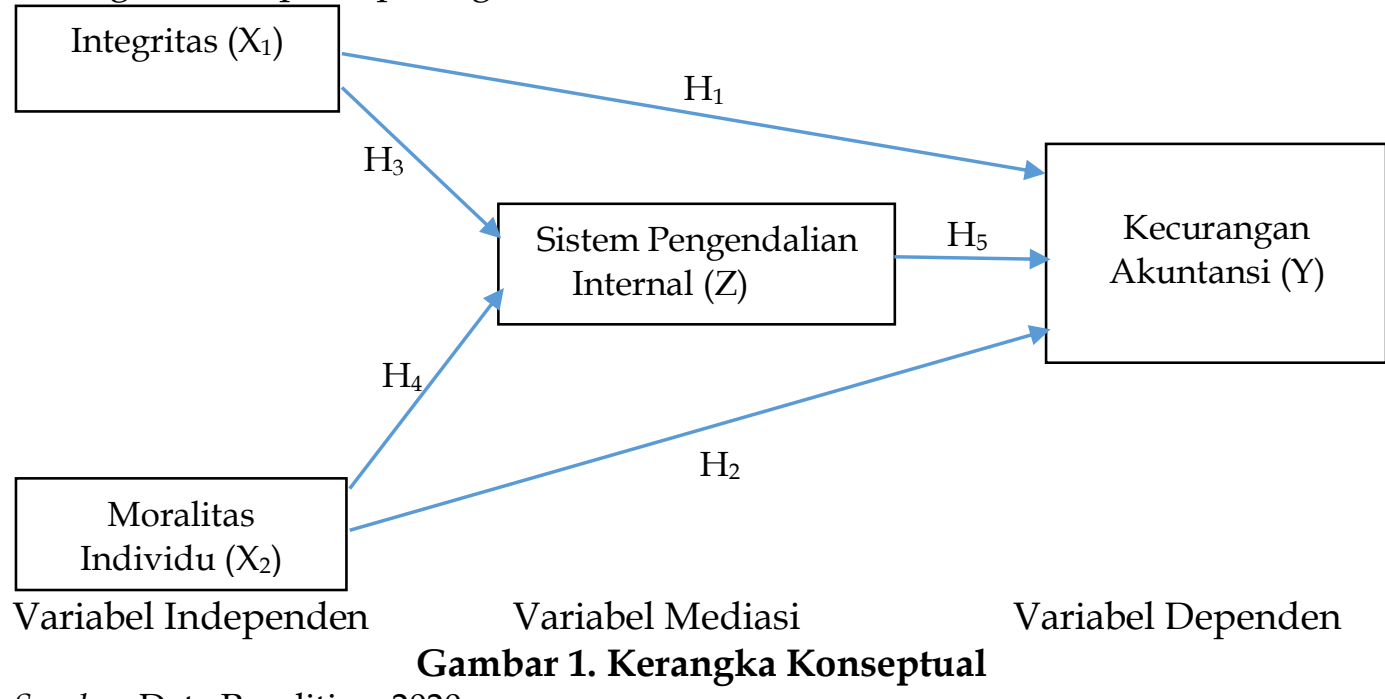

Sumber: Data Penelitian, 2020

Sihombing (2018) menjelaskan bahwa "saat ini pendekatan yang paling ampuh untuk memberantas korupsi di seluruh dunia masih berada pada upaya untuk meningkatkan standar tata pemerintahan dengan menggunakan Sistem Integritas Nasional." Integritas yang dicanangkan pada sistem seyogyanya 
sampai menyentuh kepada karyawan. Integritas karyawan atau pegawai bisa menekan terjadinya tingkat kecurangan, maka apabila integritas karyawan tinggi kecurangan akuntansi yang terjadi akan semakin rendah begitu juga sebaliknya. Penelitian Singgih et al. (2017) menyatakan bahwa integritas memiliki pengaruh yang negatif dan berdampak signifikan pada kecurangan akuntansi. Penelitian selanjutnya oleh Huslina \& Syah (2016) menyatakan bahwa integritas memiliki pengaruh terhadap pencegahan terjadinya kecurangan (fraud) akuntansi. Hal tersebut bermakna bahwa apabila integritas karyawan tinggi, maka kecurangan akuntansi yang terjadi akan semakin rendah. Begitu pun untuk system pencegahan terjadinya kecurangan akuntansi salah satu aspek yang memengaruhi adalah integritas karyawan, sehingga hubungan itu di hipotesiskan sebagai berikut.

$\mathrm{H}_{1}$ : Integritas berpengaruh negatif terhadap Kecurangan Akuntansi.

Moral adalah nilai-nilai dan norma-norma yang menjadi pegangan bagi seseorang atau suatu kelompok dalam mengatur tingkah lakunya. Dalam Yilmaz et al. (2020), Teori perkembangan moral menyatakan bahwa moral berkembang melalui tiga tahapan, yaitu tahapan preconventional, tahapan conventional dan tahapan post-conventional. Elm (2019) menyatakan bahwa "kemampuan individu dalam menyelesaikan dilema etika dipengaruhi oleh level penalaran moralnya." Seseorang yang memiliki moralitas individu pada tahapan post-conventional maka peluang untuk terjadinya kecurangan akuntansi akan semakin rendah, dan apabila seseorang yang memiliki moralitas individu pada tahapan preconventional maka peluang untuk terjadinya kecurangan akuntansi akan semakin tinggi. Setiawan (2017) menyimpulkan bahwa "moralitas individu memberi pengaruh terhadap kecurangan akuntansi, apabila moralitas individu rendah, maka akan memberi peluang yang lebih besar terhadap terjadinya kecurangan akuntansi." Penelitian lain yang dilakukan oleh Kurniawan \& Amzi (2019) mendapat hasil jika moralitas individu mempunyai pengaruh negatif pada kecenderungan terjadinya kecurangan akuntansi. Hal tersebut bermakna apabila karyawan/pegawai memiliki moralitas individu tinggi maka peluang untuk terjadinya kecurangan akuntansi akan semakin rendah, sehingga hubungan itu di hipotesiskan sebagai berikut.

$\mathrm{H}_{2}$ : Moralitas individu berpengaruh negatif terhadap kecurangan akuntansi.

Integritas merupakan salah satu karakteristik individu yang mempengaruhi perilaku individu dalam lingkungan organisasi. Salah satu unsur Pengendalian Intern dalam PP Nomor 60 Tahun 2008 adalah lingkungan pengendalian. Fernandhytia (2020) menyatakan bahwa integritas memberikan peran positif terhadap system pengendalian internal. Hal tersebut didukung pula oleh penelitian yang dilakukan oleh Shu (2018) yang menyatakan bahwa integritas dari diri pegawai bisa mengembangkan kualitas dari system pengendalian internal. Hal ini bermakna apabila integritas dari karyawan/pegawai terjaga dengan baik, maka system pengendalian yang bersifat internal akan semakin efektif. Oleh karena itu hubungan tersebut dihipotesiskan sebagai berikut.

$\mathrm{H}_{3}$ : Integritas berpengaruh positif terhadap sistem pengendalian internal.

Moralitas individu mencerminkan perilaku individu yang dalam lingkungan organisasi. Dalam teori perkembangan moral menyatakan 
kemampuan individu dalam menyelesaikan dilema etika dipengaruhi oleh level penalaran moralnya. Puspasari \& Suwardi (2016) menyatakan "jika moralitas individu berdampak signifikan terhadap pengendalian internal." Sudarman \& Kusuma (2019) yang menyatakan bahwa moralitas berinteraksi positif dengan pengendalian internal. Hal tersebut memiliki makna jika seseorang karyawan memiliki moralitas individu yang baik maka hal tersebut akan membuat karyawan memiliki pengendalian diri yang baik. Moral akan memberikan dampak positif dalam penerapan sistem pengendalian internal.

$\mathrm{H}_{4}$ : Moralitas individu berpengaruh positif terhadap sistem pengendalian internal.

Tindakan yang tidak etis dan tindakan curang dapat dipengaruhi oleh adanya sistem pengendalian internal dan monitoring oleh atasan. Sistem pengendalian internal (SPI) merupakan salah satu cara untuk dapat melakukan pengawasan atau monitoring terhadap pengelolaan keuangan. Karena dengan SPI yang baik maka suatu organisasi akan dapat berjalan dengan baik. Sistem pengendalian internal berpesan dalam menekan tindakan karyawan untuk melakukan kecurangan. Penelitian yang dilakukan oleh Yuniarti (2017) menyatakan bahwa pengendalian internal secara signifikan memberikan pengaruh pada pencegahan terjadinya kecurangan akuntansi. Artinya salah satu aspek yang perlu diperhatikan untuk pencegahan terjadinya kecurangan akuntansi adalah melalui mengoptimalkan pengendalian internal pada pegawai. Penelitian selanjutnya dilakukan oleh Sari Dewi (2016) yang memperoleh hasil bahwa apabila sistem pengendalian internal lemah, maka kecenderungan untuk melakukan kecurangan akuntansi akan semakin tinggi.

$\mathrm{H}_{5}$ : Sistem pengendalian internal berpengaruh negatif pada kecurangan akuntansi.

Penerapan integritas dan etika akan memberikan dampak positif untuk menciptakan lingkungan pengendalian yang baik. Penelitian Wulandari \& Nuryanto (2018) menyatakan bahwa integritas mempunyai pengaruh negatif terhadap kecurangan akuntansi, tetapi berpengaruh positif terhadap pencegahan terjadinya pengendalian internal.

$\mathrm{H}_{6}$ : Sistem Pengendalian Internal memediasi pengaruh Integritas Pada Kecurangan Akuntansi.

Penelitian Yadnya (2017) menyatakan "secara parsial Moralitas individu dan efektivitas system pengendalian internal berpengaruh negatif terhadap kecenderungan kecurangan akuntansi, artinya semakin efektif pengendalian internal perusahaan, semakin rendahnya kecurangan akuntansi di organisasi."

$\mathrm{H}_{7}$ : Sistem Pengendalian Internal memediasi pengaruh moralitas individu Pada Kecurangan Akuntansi.

\section{METODE PENELITIAN}

Desain penelitian yang digunakan di dalam penelitian ini dengan pendekatan kualitatif yang berbentuk asosiatif. Penelitian ini mengambil lokasi di 37 Organisasi Perangkat Daerah kabupaten Badung. Sasaran yang diamati dalam penelitian ini adalah pegawai di Organisasi Perangkat Daerah kabupaten Badung yang berstatus pegawai negeri sipil. Variabel terikat/dependen dalam penelitian ini adalah Kecurangan Akuntansi (Y). Variabel bebas dalam penelitian 
ini adalah Integritas $\left(X_{1}\right)$ dan Moralitas Individu $\left(X_{2}\right)$. Variabel Mediasi dalam penelitian ini adalah Sistem Pengendalian internal (Z). Data kualitatif yang digunakan pada penelitian ini adalah daftar pertanyaan-pertanyaan yang terdapat dalam kuesioner. Data primer dalam penelitian ini adalah jawaban responden dari kuesioner yang disebarkan.

Populasi dalam penelitian ini adalah entitas akuntansi di Organisasi Perangkat Daerah di Kabupaten Badung yang masing-masing OPD di Kabupaten Badung dipilih sebanyak 2 orang sehingga jumlah sampel 74 orang. Responden dalam penelitian ini yaitu masing-masing OPD di Kabupaten Badung sebanyak 2 orang sehingga jumlah sampel 74 orang. Pemilihan sampel tersebut karena kepala bagian keuangan memiliki otoritas dalam penyusunan laporan keuangan maupun pengelolaan keuangan OPD, sedangkan pemilihan staf bagian keuangan karena staf tersebut ikut serta dalam aktivitas pengelolaan keuangan daerah dan dipilih satu staf sebagai perwakilan sampel di masingmasing OPD. Teknik penentuan sampel yang digunakan dalam penelitian ini adalah teknik purposive sampling. Metode pengumpulan data dalam penelitian ini menggunakan adalah survei langsung ke lokasi dengan media kuesioner. Model Penelitian ini akan dianalisis menggunakan Structural Equation Model (SEM).

\section{HASIL DAN PEMBAHASAN}

Karakteristik responden menurut jenis kelamin digunakan untuk melihat seberapa banyak jumlah dan persentase antara laki-laki dan perempuan yang mengisi kuesioner, dan dapat dilihat responden dengan jenis kelamin laki-laki lebih mendominasi yakni 42 orang atau 56,8\%. Sedangkan responden dengan jenis kelamin perempuan sebanyak 32 orang atau 43,2\%. Responden lebih didominasi oleh laki-laki yang menyatakan bahwa entitas akuntansi lebih didominasi laki-laki. Responden dengan usia dari 31 - 35 tahun yang paling mendominasi diantara usia lainnya yakni 27 orang atau 36,5\%. Sedangkan responden dengan usia lebih dari 40 tahun yang paling sedikit yakni 7 orang atau 9,5\% Responden terbanyak berada pada usia 31 sampai 35 tahun sehingga diharapkan responden telah memiliki kematangan dalam berpikir serta dapat memberikan jawaban yang lebih objektif dengan pengalaman yang didapatkan.

Pendidikan terakhir yang dimiliki oleh responden didominasi oleh tingkat pendidikan S1 yaitu sebanyak 40 orang (54,1\%), 18 responden $(24,3 \%)$ memiliki pendidikan terakhir D3, 11 responden $(14,9 \%)$ memiliki pendidikan terakhir SMA, dan paling sedikit sebanyak 5 orang responden (6,8\%) memiliki pendidikan terakhir S2. Responden dengan pendidikan terakhir S1 yang paling mendominasi diantara pendidikan lainnya yakni 40 orang atau $54,1 \%$. Sedangkan responden yang paling sedikit adalah responden dengan pendidikan terakhir S2 yakni 5 orang atau 6,8\%. Responden dengan lama bekerja $6-10$ Tahun yang paling mendominasi diantara lama bekerja lainnya yakni 40 orang atau $54,1 \%$. Sedangkan responden yang paling sedikit adalah responden dengan lama bekerja lebih dari 10 tahun yakni 12 orang atau 16,2\%. Kriteria lama bekerja dapat menjelaskan seberapa lama responden telah menduduki jabatan dan telah mengabdikan dirinya, serta dapat pula menunjukkan pengalaman yang telah dimiliki sebagai entitas akuntansi. 
Nilai $R$-square untuk variabel Integritas terhadap Kecurangan akuntansi sebesar 0,739 menunjukkan memiliki besar pengaruh $0,739 \times 100 \%=73,9 \%$. Nilai R-square untuk variabel Integritas terhadap Sistem pengendalian internal sebesar 0,556 termasuk baik yang menunjukkan memiliki besar pengaruh $0,556 \mathrm{x}$ $100 \%=55,6 \%$.

Tabel 1. Hasil Uji Pengaruh Langsung

\begin{tabular}{llllll}
\hline & $\begin{array}{c}\text { Sampel } \\
\text { Asli (O) }\end{array}$ & $\begin{array}{c}\text { Rata-rata } \\
\text { Sampel } \\
(\mathrm{M})\end{array}$ & $\begin{array}{c}\text { Standar } \\
\text { Deviasi } \\
(\text { STDEV) }\end{array}$ & $\begin{array}{c}\text { T } \\
\text { Statistik }\end{array}$ & P Values \\
\hline $\begin{array}{l}\text { Integritas (X1) -> } \\
\begin{array}{l}\text { Kecurangan Akuntansi (Y) } \\
\text { Integritas (X1) -> Sistem }\end{array}\end{array}$ & -0.421 & -0.452 & 0.176 & 2.385 & 0.020 \\
$\begin{array}{l}\text { Pengendalian Internal (Z) } \\
\text { Moralitas Individu (X2) -> }\end{array}$ & -0.273 & 0.675 & 0.096 & 6.756 & 0.000 \\
$\begin{array}{l}\text { Kecurangan Akuntansi (Y) } \\
\text { Moralitas Individu (X2) -> }\end{array}$ & 0.231 & 0.215 & 0.106 & 2.179 & 0.032 \\
$\begin{array}{l}\text { Sistem Pengendalian } \\
\text { Internal (Z) }\end{array}$ & & & & & \\
$\begin{array}{l}\text { Sistem Pengendalian } \\
\text { Internal (Z) -> Kecurangan } \\
\text { Akuntansi (Y) }\end{array}$ & -0.357 & -0.317 & 0.154 & 2.314 & 0.023 \\
\hline
\end{tabular}

Sumber: Data Penelitian, 2020

Nilai p-value variabel integritas terhadap kecurangan akuntansi sebesar 0,020 yang dibandingkan dengan signifikan sebesar 0,05 . Karena nilai $p$-value < signifikan $(0,020<0,05)$ dengan nilai beta sebesar negatif $-0,421$ dan nilai $\mathrm{t}$ statistics sebesar 2,385 yang dibandingkan dengan t-tabel sebesar 1,96. Karena nilai t-statistics $>$ t-value $(2,385>1,96)$ maka dapat disimpulkan bahwa Integritas berpengaruh negatif signifikan terhadap kecurangan akuntansi. Nilai $p$-value variabel Integritas terhadap sistem pengendalian internal sebesar 0,000 yang dibandingkan dengan signifikan sebesar 0,05. Karena nilai $p$-value $<$ signifikan $(0,000<0,05)$ dengan nilai beta sebesar positif 0,647 dan nilai $t$ statistics sebesar 6,756 yang dibandingkan dengan t-tabel sebesar 1,96. Karena nilai t-statistics $>\mathrm{t}$ value $(6,756>1,96)$ maka dapat disimpulkan bahwa Integritas berpengaruh positif signifikan terhadap sistem pengendalian internal.

Nilai $p$-value variable moralitas terhadap kecurangan akuntansi sebesar 0,001 yang dibandingkan dengan signifikan sebesar 0,05. Karena nilai $p$-value < signifikan $(0,001<0,05)$ dengan nilai beta sebesar negatif $-0,273$ dan nilai $t$ statistics sebesar 3,583 yang dibandingkan dengan t-tabel sebesar 1,96. Karena nilai t-statistics $>$ t-value $(3,583>1,96)$ maka dapat disimpulkan bahwa moralitas individu berpengaruh negatif signifikan terhadap kecurangan akuntansi. Nilai $p$ value variable moralitas terhadap sistem pengendalian internal sebesar 0,032 yang dibandingkan dengan signifikan sebesar 0,05. Karena nilai p-value < signifikan $(0,032<0,05)$ dengan nilai beta sebesar positif 0,231 dan nilai $t$ statistics sebesar 2,179 yang dibandingkan dengan t-tabel sebesar 1,96. Karena nilai t-statistics $>$ t-value $(2,179>1,96)$ maka dapat disimpulkan bahwa moralitas individu berpengaruh positif signifikan terhadap sistem pengendalian internal. Nilai $p$-value variabel sistem pengendalian internal terhadap kecurangan akuntansi sebesar 0,023 yang dibandingkan dengan signifikan sebesar 0,05. 
Karena nilai $p$-value $<$ signifikan $(0,023<0,05)$ dengan nilai beta sebesar negatif 0,357 dan nilai $t$ statistics sebesar 2,314 yang dibandingkan dengan $t$-tabel sebesar 1,96. Karena nilai t-statistics $>\mathrm{t}$-value $(2,314>1,96)$ maka dapat disimpulkan bahwa sistem pengendalian internal berpengaruh negatif signifikan terhadap kecurangan akuntansi.

Tabel 2. Hasil Uji Pengaruh Tidak Langsung

\begin{tabular}{lllllr} 
& $\begin{array}{l}\text { Sampel } \\
\text { Asli (O) }\end{array}$ & $\begin{array}{l}\text { Rata-rata } \\
\text { Sampel (M) }\end{array}$ & $\begin{array}{l}\text { Standar } \\
\text { Deviasi }\end{array}$ & $\begin{array}{l}\text { T } \\
\text { Statistik }\end{array}$ & P Values \\
\hline $\begin{array}{l}\text { Integritas (X1) -> Sistem } \\
\text { Pengendalian Internal (Z) - }\end{array}$ & -0.231 & -0.206 & 0.094 & 2.448 & 0.017 \\
$\begin{array}{l}>\text { Kecurangan Akuntansi } \\
\text { (Y) }\end{array}$ & & & & & \\
$\quad \begin{array}{l}\text { Moralitas Individu (X2) -> } \\
\quad \text { Sistem Pengendalian }\end{array}$ & -0.082 & -0.076 & 0.060 & 1.374 & 0.174 \\
$\begin{array}{l}\text { Internal (Z) -> Kecurangan } \\
\text { Akuntansi (Y) }\end{array}$ & & & & & \\
\hline Sumber: Data Penelitian, 2020 & & & & \\
\hline
\end{tabular}

Nilai p-value variabel Integritas terhadap kecurangan akuntansi melalui Sistem pengendalian internal sebesar 0,017 yang dibandingkan dengan signifikan sebesar 0,05. Karena nilai $p$-value < signifikan $(0,017<0,05)$ dengan nilai beta sebesar negatif $-0,231$ dan nilai $t$ statistics sebesar 2,448 yang dibandingkan dengan $\mathrm{t}$-tabel sebesar 1,96 . Karena nilai $\mathrm{t}$-statistics $>\mathrm{t}$-value $(2,448>1,96)$ maka dapat disimpulkan bahwa Integritas berpengaruh negatif signifikan terhadap kecurangan akuntansi melalui Sistem pengendalian internal. Nilai p-value variabel moralitas individu terhadap kecurangan akuntansi melalui Sistem pengendalian internal sebesar 0,174 yang dibandingkan dengan signifikan sebesar 0,05 . Karena nilai $p$-value $>$ signifikan $(0,174>0,05)$ dengan nilai beta sebesar negatif $-0,082$ dan nilai $\mathrm{t}$ statistics sebesar 1,374 yang dibandingkan dengan t-tabel sebesar 1,96. Karena nilai t-statistics < t-value $(1,374<1,96)$ maka dapat disimpulkan bahwa moralitas individu tidak berpengaruh negatif signifikan terhadap kecurangan akuntansi melalui sistem pengendalian internal.

Nilai p-value variabel integritas terhadap kecurangan akuntansi sebesar 0,020 yang dibandingkan dengan signifikan sebesar 0,05 , karena nilai $p$-value < signifikan $(0,020<0,05)$ maka pengaruh langsung integritas terhadap kecurangan akuntansi signifikan. Nilai $p$-value variabel moralitas individu terhadap kecurangan akuntansi sebesar 0,001 yang dibandingkan dengan signifikan sebesar 0,05, karena nilai $p$-value < signifikan $(0,001<0,05)$ maka pengaruh langsung moralitas individu terhadap kecurangan akuntansi signifikan, selanjutnya dilakukan pengujian tidak langsung.

Nilai $p$-value variabel Integritas terhadap kecurangan akuntansi melalui Sistem pengendalian internal sebesar 0,017 yang dibandingkan dengan signifikan sebesar 0,05, karena nilai $p$-value < signifikan $(0,017<0,05)$ maka pengaruh tidak langsung variabel Integritas terhadap kecurangan akuntansi signifikan. Nilai $p$ value variabel moralitas individu terhadap kecurangan akuntansi melalui Sistem pengendalian internal sebesar 0,174 yang dibandingkan dengan signifikan sebesar 0,05 , karena nilai $p$-value $>$ signifikan $(0,174>0,05)$ maka pengaruh tidak 
langsung variabel Moralitas individu terhadap kecurangan akuntansi tidak signifikan. Pengaruh tidak langsung variabel Moralitas individu terhadap kecurangan akuntansi tidak signifikan yang menyatakan pengaruh variabel moralitas individu pada kecurangan akuntansi melalui sistem pengendalian internal tidak terdapat mediasi.

Nilai Variance Accounted For (VAF) adalah 0,354 atau 35,4\% yang berarti variabel Integritas terhadap kecurangan akuntansi melaui sistem pengendalian internal termasuk ke dalam maka mediasi parsial. Mediasi parsial yang berarti variabel independent mampu mempengaruhi secara langsung variabel dependen tanpa melalui variabel mediator.

Berdasarkan hasil analisis pengaruh Integritas terhadap Kecurangan akuntansi diperoleh nilai Signifikansi sebesar 0,020 dengan nilai koefisien beta 0,421 bernilai negatif. Nilai Signifikansi 0,020 < 0,05 mengindikasikan bahwa $\mathrm{H}_{0}$ ditolak dan $\mathrm{H}_{1}$ diterima. Hasil ini mempunyai arti bahwa Integritas berpengaruh negatif terhadap Kecurangan akuntansi. Hal ini menandakan semakin tinggi nilai Integritas maka Kecurangan akuntansi akan menurun, begitu juga sebaliknya. Penelitian Singgih et al. (2017) menyatakan bahwa integritas memiliki pengaruh yang negatif dan berdampak signifikan pada kecurangan akuntansi. Penelitian selanjutnya oleh Huslina \& Syah (2016) menyatakan bahwa integritas memiliki pengaruh terhadap pencegahan terjadinya kecurangan (fraud) akuntansi.

Berdasarkan hasil analisis pengaruh moralitas individu terhadap Kecurangan akuntansi diperoleh nilai Signifikansi sebesar 0,001 dengan nilai koefisien beta $-0,273$ bernilai negatif. Nilai Signifikansi 0,001 $<0,05$ mengindikasikan bahwa $\mathrm{H}_{0}$ ditolak dan $\mathrm{H}_{2}$ diterima. Hasil ini mempunyai arti bahwa moralitas individu berpengaruh negatif terhadap Kecurangan akuntansi. Dalam Yilmaz et al. (2020), teori perkembangan moral menyatakan bahwa moral berkembang melalui tiga tahapan, yaitu tahapan preconventional, tahapan conventional dan tahapan post-conventional. Penelitian yang dilakukan oleh Setiawan (2017) menyimpulkan bahwa moralitas individu memberi pengaruh terhadap kecurangan akuntansi, apabila moralitas individu rendah, maka akan memberi peluang yang lebih besar terhadap terjadinya kecurangan akuntansi. Penelitian lain yang dilakukan oleh Kurniawan \& Amzi (2019) mendapat hasil jika moralitas individu mempunyai pengaruh negatif pada kecenderungan terjadinya kecurangan akuntansi.

Berdasarkan hasil analisis pengaruh integritas terhadap sistem pengendalian internal diperoleh nilai Signifikansi sebesar 0,000 dengan nilai koefisien beta 0,647 bernilai positif. Nilai Signifikansi 0,000 $<0,05$ mengindikasikan bahwa $\mathrm{H}_{0}$ ditolak dan $\mathrm{H}_{3}$ diterima. Hasil ini mempunyai arti bahwa integritas berpengaruh positif terhadap sistem pengendalian internal. Hal ini menandakan semakin tinggi nilai integritas maka sistem pengendalian internal akan meningkat, begitu juga sebaliknya. Penelitian yang dilakukan oleh Fernandhytia (2020) menyatakan bahwa integritas memberikan peran positif terhadap system pengendalian internal. Hal tersebut didukung pula oleh penelitian yang dilakukan oleh Shu (2018) yang menyatakan bahwa integritas 
dari diri pegawai bisa mengembangkan kualitas dari system pengendalian internal.

Berdasarkan hasil analisis pengaruh moral individu terhadap sistem pengendalian internal diperoleh nilai Signifikansi sebesar 0,032 dengan nilai koefisien beta 0,231 bernilai positif. Nilai Signifikansi 0,032 $<0,05$ mengindikasikan bahwa $\mathrm{H}_{0}$ ditolak dan $\mathrm{H}_{4}$ diterima. Hasil ini mempunyai arti bahwa moral individu berpengaruh positif terhadap sistem pengendalian internal. Penelitian ini didukung oleh Sudarman \& Kusuma (2019) yang menyatakan bahwa moralitas berinteraksi positif dengan pengendalian internal.

Berdasarkan hasil analisis pengaruh sistem pengendalian internal terhadap Kecurangan akuntansi diperoleh nilai Signifikansi sebesar 0,023 dengan nilai koefisien beta $-0,357$ bernilai negatif. Nilai Signifikansi 0,023<0,05 mengindikasikan bahwa $\mathrm{H}_{0}$ ditolak dan $\mathrm{H}_{5}$ diterima. Hasil ini mempunyai arti bahwa sistem pengendalian internal berpengaruh negatif terhadap Kecurangan akuntansi. Penelitian yang dilakukan oleh Yuniarti (2017) menyatakan bahwa pengendalian internal secara signifikan memberikan pengaruh pada pencegahan terjadinya kecurangan akuntansi.

Berdasarkan hasil analisis pengaruh integritas terhadap Kecurangan akuntansi melalui system pengendalian internal diperoleh nilai Signifikansi sebesar 0,017 dengan nilai koefisien beta -0,231 bernilai negatif. Nilai Signifikansi 0,017 < 0,05 mengindikasikan bahwa $\mathrm{H}_{0}$ ditolak dan $\mathrm{H}_{6}$ diterima. Hasil ini mempunyai arti bahwa integritas berpengaruh negatif terhadap Kecurangan akuntansi melalui system pengendalian internal. Nilai Variance Accounted For (VAF) pengaruh integritas terhadap Kecurangan akuntansi melalui system pengendalian internal adalah 0,354 atau $35,4 \%$ yang berarti sistem pengendalian internal memediasi secara parsial pengaruh negatif signifikan integritas pada kecurangan akuntansi. Semakin tinggi tingkat integritas seseorang maka akan memperkecil tindakan kecurangan. Penerapan integritas dan etika akan memberikan dampak positif untuk menciptakan lingkungan pengendalian yang baik. Penelitian Wulandari \& Nuryanto (2018) menyatakan bahwa integritas mempunyai pengaruh negatif terhadap kecurangan akuntansi.

Berdasarkan hasil analisis pengaruh moralitas individu terhadap Kecurangan akuntansi melalui sistem pengendalian internal diperoleh nilai Signifikansi sebesar 0,174 dengan nilai koefisien beta $-0,082$ bernilai negatif. Nilai Signifikansi 0,174 > 0,05 mengindikasikan bahwa $\mathrm{H}_{0}$ diterima dan $\mathrm{H}_{7}$ ditolak. Hasil ini mempunyai arti bahwa moralitas individu berpengaruh negatif terhadap Kecurangan akuntansi, karena pengaruh tidak langsung moralitas pada kecurangan melalui sistem pengendalian internal tidak signifikan menyatakan tidak ada mediasi. Penelitian Yadnya (2017) menyatakan "secara parsial Moralitas individu dan efektivitas system pengendalian internal berpengaruh negatif terhadap kecenderungan kecurangan akuntansi, artinya semakin efektif pengendalian internal perusahaan, semakin rendahnya kecurangan akuntansi di organisasi."

\section{SIMPULAN}

Integritas berpengaruh negatif terhadap kecurangan akuntansi. Hal ini menunjukan bahwa jika Integritas semakin meningkat maka Kecurangan 
akuntansi akan menurun. Moralitas individu berpengaruh negatif terhadap Kecurangan akuntansi. Hal ini menunjukan bahwa jika moralitas individu semakin meningkat maka Kecurangan akuntansi akan menurun. Integritas berpengaruh positif terhadap sistem pengendalian internal. Hal ini menunjukan bahwa jika Integritas semakin meningkat maka sistem pengendalian internal akan meningkat pula. Moralitas Individu berpengaruh positif terhadap sistem pengendalian internal. Hal ini menunjukan bahwa jika Moralitas Individu semakin meningkat maka sistem pengendalian internal akan meningkat pula. Sistem pengendalian internal berpengaruh negatif terhadap Kecurangan akuntansi. Hal ini menunjukan bahwa jika Sistem pengendalian internal individu semakin meningkat maka Kecurangan akuntansi akan menurun. Sistem pengendalian internal memediasi secara parsial pengaruh negatif Integritas terhadap Kecurangan akuntansi. Integritas mampu mempengaruhi kecurangan akuntansi tanpa atau dengan sistem pengendalian internal sebagai mediasi. Sistem pengendalian internal tidak memediasi pengaruh negatif Moralitas Individu terhadap Kecurangan akuntansi. Moralitas individu tidak mampu mempengaruhi kecurangan akuntansi melalui sistem pengendalian internal.

Mengoptimalkan integritas pegawai agar memiliki sikap yang tepat dalam proses kinerja sehingga kecurangan akuntansi tidak ditemukan pada perusahaan dengan menanamkan rasa loyalitas terhadap instansi. Melakukan monitoring oleh atasan untuk bawahan sehingga kinerja pegawai akan sesuai dengan aturan yang dapat memperkecil kemungkinan terjadinya kecurangan akuntansi. Memperhatikan dan melakukan evaluasi terhadap peraturan sebagai sistem pengendalian internal karena dapat mempengaruhi pengaruh integritas terhadap kecurangan akuntansi. Sehingga dengan memperhatikan sistem pengendalian internal dapat meminimalisir kecurangan individu.

\section{REFERENSI}

Chandrayatna, P. (2019). Pengaruh Pengendalian Internal, Moralitas Individu Dan Budaya Etis Organisasi Pada Kecenderungan Kecurangan Akuntansi. E-Jurnal Fakultas Ekonomi Dan Bisnis, 27(1), 1063-1093.

Coram. (2018). Internal audit, alternative internal audit tructures and the level of misapropriation of assets fraud. Accounting and Finance, 48(2), 1-20.

Donelson, D. C., \& Ege, M. (2019). Internal Control Weaknesses and Financial Reporting Fraud Dain. Research Gate, 53(9), 1689-1699. https:// doi.org/10.1017/CBO9781107415324.004

Eliza, Y. (2015). Pengaruh Moralitas Individu dan Pengendalian Internal terhadap Kecenderungan Kecurangan Akuntansi (Studi Empiris pada SKPD di Kota Padang). Jurnal Akuntansi, 4(1), 86-100. https:// doi.org/https:/ / doi.org/10.1017/CBO9781107415324.004

Elm, D. R. (2019). Cognitive Moral Development in Ethical Decision-making. Business Ethics, 3(1), 1-20.

Fernandhytia, F. (2020). The Effect Of Internal Control, Individual Morality And Ethical Value On Accounting Fraud Tendency. Accounting Analysis Journal, 35(1), 112 - 127.

Huslina, H., \& Syah, N. (2016). Pengaruh Integritas Aparatur, Kompetensi 
Aparatur, Dan Pemanfaatan Teknologi Informasi Terhadap Efektivitas Sistem Pencegahan Fraud. Jurnal Magister Akuntansi, 4(1), 55 - 64.

Ilter, C. (2017). Misrepresentation of Financial Statements: An Accounting Fraud Case from Turkey. SSRN Electronic Journal, 21(2), 1-20.

Junaidi, \& Siti. (2017). Culture And Its Effect On Fraud With Intervening Morality Variable. Research Gate, 4(1), 55 - 64.

Kurniawan, P. C., \& Amzi, F. (2019). The Effect of Management Morality on Accounting Fraud with Internal Control as A Moderating Variable (Study in Pemalang Regency). Accounting Research Journal, 4(2), 177 - 185.

Lestari, N. K. L., \& Supadmi, N. L. (2017). Pengaruh Pengendalian Internal, Integritas, dan Asimetri Informasi pada Kecurangan Akuntansi. E-Jurnal Akuntansi, 21(1), 389-417.

Lestari, N. L. W. T., \& Dewi, N. N. S. R. T. (2020). Pengaruh Pemahaman Akuntansi, Pemanfaatan Sistem Informasi Akuntansi Dan Sistem Pengendalian Intern Terhadap Kualitas Laporan Keuangan. Jurnal Akuntansi Sekolah Tinggi Ilmu Ekonomi Triatma Mulya Badung Bali, 1(1), 1-20.

Locatelli, G. (2017). Accounting fraud can be said to be a tendency for corruption in the definition and terminology because of the involvement of several elements consisting of misleading facts, violation of rules or abuse of trust, and omission of critical facts. International Journal of Project Management, 35(3), 252-268.

Prihartono, T., \& Mayangsari, S. (2018). Pengaruh Integritas, Objektivitas, Dan Kompetensi Auditor Internal Terhadap Efektivitas Audit Internal Dengan Gaya Kepemimpinan Demokrasi Sebagai Variabel Moderasi Pada Inspektorat Jenderal Kementerian Dalam Neger. Jurnal Magister Akuntansi Trisakti, 5(1), 63 - 88.

Puspasari, N., \& Suwardi, E. (2016). the Effect of Individual Morality and Internal Control on the Propensity To Commit Fraud: Evidence From Local Governments. Journal of Indonesian Economy and Business, 31(1), 208. https:// doi.org/10.22146/jieb.15291

Sari Dewi, G. A. K. R. (2016). Pengaruh Moralitas Individu Dan Pengendalian Internal Pada Kecurangan Akuntansi (Studi Eksperimen Pada Pemerintah Daerah Provinsi Bali). Jurnal Ilmiah Akuntansi, 1(1), 77 - 92.

Setiawan, S. (2017). The Effect Of Internal Control And Individual Morality On The Tendency Of Accounting Fraud. Asia Pasific Fraud Journal, 33 - 41.

Shu, W. (2018). Does Corporate Integrity Improve The Quality of Internal Control. China Jurnal of Accounting Research, 11(1), 407 - 427.

Sihombing, S. (2018). Youth perceptions toward corruption and integrity: Indonesian context. Kasetsart Journal of Social Sciences, 39(2), 299-304.

Singgih, D. W., Yuliati, N., \& Amrul, R. (2017). Pengaruh Pengendalian Internal Dan Integritas Pada Kecenderungan Kecurangan Akuntansi (Studi Kasus Pada Dinas Skpd Kota Mataram). Accounting Analysys Journal AAJ1, 2(1), 120.

Suci, P. F., \& Lisda, R. (2016). Pengaruh Pengendalian Internal Terhadap Pencegahan Kecurangan (Fraud) Dan Dampaknya Pada Kinerja Perusahaan (Studi Pada Kantor Cabang Utama PT. Bank Negara Indonesia (Persero). Jurnal, Universitas Pasundan Bandung., 1(1), 1-20. 
Sudarman, \& Kusuma, S. Y. (2019). Individual morality to accounting fraud tendency at whole bmts in kudus. International Journal of Scientific and Technology Research, 8(12), 1889-1892.

Udayani, A. A. K. F., \& Sari, M. M. R. (2017). Pengaruh Pengendalian Internal dan Moralitas Individu pada Kecenderungan Kecurangan Akuntansi. EJurnal Akuntansi Universitas Udayana, 18(3), 1774-1799. https://doi.org/https://doi.org/10.24036/20171115

Wulandari, D. N., \& Nuryanto, M. (2018). Pengaruh Pengendalian Internal, Kesadaran Anti-Fraud, Integritas, Independensi, Dan Profesionalisme Terhadap Pencegahan Kecurangan. JRAMB, 4(2), 117 - 125.

Yadnya, M. D. (2017). Pengaruh Moralitas Individu, Efektivitas Sistem Pengendalian Internal, Dan Ketaatan Aturan Akuntansi Terhadap Kecenderungan Kecurangan (Fraud) (Studi Kasus Pada Ksp Kecamatan Buleleng). Jurnal Akuntansi, 7(1), 1-20.

Yilmaz, O., Bahçekapili, H. G., \& Sevi, B. (2020). Theory of Moral Development. Encyclopedia of Evolutionary Psychological Science, 1(6), 1-6. https:/ / doi.org/10.1007/978-3-319-16999-6

Yuniarti, R. D. (2017). The effect of internal control and anti-fraud awareness on fraud prevention (A survey on inter-governmental organizations). Journal of Economics, Business, and Accountancy Ventura, 20(1), 113 - 124.

Zager, L., Malis, S. S., \& Novak, A. (2016). The Role and Responsibility of Auditors in Prevention and Detection of Fraudulent Financial Reporting. Procedia Economics and Finance, 39(November 2015), 693-700. https:/ / doi.org/10.1016/s2212-5671(16)30291-x 